\title{
Rhamnus davurica leaf extract inhibits Fyn activation by antigen in mast cells for anti-allergic activity
}

Ji Hyung Kim ${ }^{1 \dagger}$, A-Ram Kim ${ }^{1 \dagger}$, Hyuk Soon Kim ${ }^{1}$, Hyun Woo Kim', Young Hwan Park', Jueng Soo You', Yeong Min Park', Erk Her ${ }^{1}$, Hyung Sik Kim², Young Mi Kim³ and Wahn Soo Choi ${ }^{3 *}$

\begin{abstract}
Background: Complementary and alternative herbal medicines are recently considered as a promising approach for treating various diseases. We screened approximately 100 plant extracts for anti-allergic activity. Rhamnus davurica leaf extract showed the most potent inhibitory effect on the activation of RBL-2H3 mast cells. Although Rhamnus davurica extract has been used to treat pruritus, dysuresia, and constipation as a traditional herbal medicine in some Asian countries, an anti-allergic effect of Rhamnus davurica has not yet been demonstrated. We aimed to investigate the effect and mechanism of the leaf extract of Rhamnus davurica (LERD) on mast cells in vitro and allergic responses in vivo.
\end{abstract}

Methods: The effects of LERD on the activation of mast cells and mast cell-mediated passive cutaneous anaphylaxis (PCA) were measured in mice and two types of mast cells, mouse bone marrow-derived mast cells (BMMCs) and RBL-2H3 cells in vitro. A mechanistic study of its inhibitory effect was performed by using degranulation assay, reverse transcriptase-polymerase chain reaction, enzyme-linked immunosorbent assay, and western blotting analysis.

Results: LERD reversibly suppressed antigen-stimulated degranulation in BMMCs and RBL-2H3 cells, and also inhibited mRNA expression and secretion of TNF- $\alpha$ and IL-4 in a dose-dependent manner. In a PCA animal model, LERD significantly inhibited antigen-induced allergic response and degranulation of ear tissue mast cells. As for the mechanism of action, LERD inhibited the activation of Syk, which is the pivotal signaling protein for mast cell activation by antigen. Furthermore, LERD also impeded the activations of well-known downstream proteins such as LAT, Akt and three MAP kinases (Erk, p38 and JNK). In an in vitro kinase assay, LERD suppressed the activation of Fyn in antigen-stimulated mast cells.

Conclusion: This study demonstrated for the first time that LERD has anti-allergic effects through inhibiting the Fyn/Syk pathway in mast cells. Therefore, this study provides scientific evidence for LERD to be used as an herbal medicine or health food for patients with allergic diseases.

Keywords: Rhamnus davurica, Herbal medicine, Mast cells, Allergy, Anaphylaxis, Fyn

\footnotetext{
* Correspondence: wahnchoi@kku.ac.kr

${ }^{\dagger}$ Equal contributors

'KU open Innovation Center, School of Medicine, Konkuk University, Chungju 380-701, Korea

Full list of author information is available at the end of the article
} 


\section{Background}

Allergic diseases such as allergic asthma, allergic rhinitis, and atopic dermatitis have been increasing, particularly in many developed countries. Generally, around 10 to $20 \%$ of the population are reported as presenting with allergic diseases in those countries [1,2]. Usually, patients with allergy-prone genetic factors have type 2 helper $\mathrm{T}$ cells (Th2) reactions under a certain environment. When patients are exposed to potential allergens such as milk, egg, nuts, and shellfish, various allergic symptoms may occur. In the course of early and late allergic reactions, mast cells are solidly acknowledged as one of the major culprit effector cells [3].

Mast cells play a key role in prompting a variety of allergic symptoms [4,5]. Mast cells have FceRI, a highaffinity receptor for IgE, which makes a complex with antigen-specific IgE. When mast cells are stimulated by an antigen, various allergic mediators including histamines, eicosanoids, and pro-inflammatory cytokines are secreted from mast cells [6,7]. Thus, mast cells play a critical role in causing allergic diseases, and therefore mast cells-stabilizing therapies have been increasingly reported $[8,9]$.

When mast cells are stimulated by antigens, the initial activation of Lyn or other Src-family kinases is observed for the phosphorylation of an immunoreceptor tyrosine activation motif (ITAM) of FceRI $\gamma$ subunit and Syk is, then, recruited to tyrosine phosphorylated ITAMs for the full activation of Syk [10,11]. This event leads to the activation of downstream signaling molecules including a linker for the activation of T cells (LAT), SLP-76, Gab2, phospholipase (PL) Cy, and MAP kinases. This series of activations of signaling proteins leads to the full activation of mast cells in prompting allergic responses [12,13].

The Src family kinases, including Lyn, Fyn, and Fgr, are activated by antigen stimulation in mast cells [11]. The initial activation of Lyn is essential for the activation of mast cells, and Lyn additionally also has a negative role in mitigating the excess activation of mast cells [14]. Whereas Fyn and Fgr show solely a positive role in the activation of Syk and its downstream signaling cascades for mast cell activation [11]. Therefore, a Src-family kinase-targeted study could be an efficient direction for treatment of allergic diseases.

Rhamnus davurica is widely found throughout fields of Korea, China, and other Asian countries. Extract of Rhamnus davurica has long been in use as a folk remedy in the treatment of several diseases including pruritus, dysuresia, and constipation. However, the effect of Rhamnus davurica on allergic diseases remains to be unclear.

In this study, we investigated the anti-allergic effects of the leaf extract of Rhamnus davurica (LERD) in mast cells cultures and in passive cutaneous anaphylaxis animal models. LERD suppressed the activation of mast cells and anaphylaxis responses through the inhibition of the activation of Fyn/Syk pathway in antigen-stimulated mast cells.

\section{Methods \\ Reagents}

Antibodies that work against the phosphorylated forms of Akt, Erk1/2, p38, JNK, Syk (Y525/526), and LAT (Y191) were obtained from Cell Signaling Technology, Inc. (Danvers, MA, USA). The 4-Amino-5-(4-chlorophenyl)7-(dimethylethyl)pyrazolo [3,4- $d]$ pyrimidine (PP2) was obtained from Calbiochem (La Jolla, CA, USA). Enzymelinked immunosorbant assay (ELISA) kits for analyzing IL-4 in media was obtained from Invitrogen-Biosource Cytokine \& Signaling (Camarillo, CA, USA). An ELISA kit for TNF- $\alpha$ measurement was from R\&D Systems, Inc. (Minneapolis, MN, USA). Reagents for cell culture media were obtained from GIBCO/Life Technologies, Inc. (Rockville, MD, USA). Most of all the other reagents used were purchased from Sigma-Aldrich (St. Louis, MO, USA).

\section{Animals}

$\mathrm{BALB} / \mathrm{c}$ mice (5-weeks old) were used for the isolation of bone marrow-derived mast cells (BMMCs) and the induction of passive cutaneous anaphylaxis (PCA). All animal studies were performed according to institutional guidelines after obtaining approval from the Institutional Animal Care and Use Committee (IACUC) at Konkuk University.

\section{Mast cell preparation and cell culture}

BMMCs were isolated from the thigh bones of 5 weekold BALB/c mice as in previous studies [15]. The BMMCs were cultured in media (RPMI 1640), containing $2 \mathrm{mM}$ L-glutamine, $0.1 \mathrm{mM}$ nonessential amino acids, antibiotics, and $10 \%$ fetal bovine serum (FBS) containing $10 \mathrm{ng} / \mathrm{ml} \mathrm{IL-3} \mathrm{in} 5 \% \mathrm{CO}_{2}, 37^{\circ} \mathrm{C}$ incubator. Four weeks following isolation, the BMMCs were used for the following experiments. The RBL-2H3 cells from ATCC (American Type Culture Collection, VA, USA) were cultured in a minimum essential medium (MEM) with Earle's salts, supplemented with glutamine, antibiotics, and $15 \%$ FBS.

\section{Preparation of LERD and other plant extracts}

Leaf of Rhamnus davurica was collected from Hantaek Botanical Garden (Yongin-si, Korea) and was authenticated by the Plant Extract Bank at the Korea Research Institute of Bioscience and Biotechnology (Daejeon, Korea). The methanol extracts of Rhamnus davurica leaf (LERD) and other plants were manufactured according to the institute's standard protocol. The yield of the extraction process was approximately $15 \%$ of total dry leaf amount. The extracted and plant specimen (017-005 for LERD or as indicated in Table 1) were deposited at the Plant 
Table 1 Effects of plant extracts on the Ag-induced degranulation in RBL-2H3 mast cells

\begin{tabular}{|c|c|c|c|}
\hline Plant name & Part extracted & Voucher specimen number & Percent inhibition of degranulation $^{\mathrm{a}}$ \\
\hline Acer okamotoanum & Stem-bark & 016-081 & 0.00 \\
\hline Acer ukurunduense & Leaf & 016-050 & 40.78 \\
\hline Acer ukurunduense & Stem & 016-051 & 30.32 \\
\hline ActinoStemma lobatum & Whole plant & 017-038 & 18.48 \\
\hline Ardisia pusilla & Whole plant & 016-061 & 0.00 \\
\hline Aster incisa & Whole plant & 016-001 & 0.00 \\
\hline Berberis amurensis var. quelpaertensis & Stem & 016-069 & 16.96 \\
\hline Betula chinensis & Leaf & 017-013 & 39.17 \\
\hline Betula chinensis & Stem & 017-014 & 27.76 \\
\hline Betula davurica & Stem & 017-045 & 3.78 \\
\hline Betula davurica & Stem-bark & 017-046 & 0.00 \\
\hline Betula ermani var. saitoana & Leaf & 016-089 & 10.80 \\
\hline Betula ermani var. saitoana & Stem & 016-090 & 1.78 \\
\hline Boehmeria pannosa & Whole plant & 016-080 & 0.43 \\
\hline Bupleurum longeradiatum & Whole plant & 017-016 & 29.22 \\
\hline Cacalia auriculata var. matsumurana & Whole plant & 016-047 & 12.05 \\
\hline Campylotropis macrocarpa & Aboveground part & 017-023 & 0.00 \\
\hline Celosia argentea & Whole plant & 017-012 & 38.14 \\
\hline Chaenomeles sinensis & Leaf & 017-040 & 3.85 \\
\hline Cinnamomum loureirii & Leaf & 016-082 & 5.92 \\
\hline Clerodendrum trichotomum & Leaf & 016-026 & 2.27 \\
\hline Clintonia udensis & Whole plant & 016-019 & 51.37 \\
\hline Corydalis heterocarpa & Whole plant & 016-079 & 11.79 \\
\hline Crataegus scabrida & fruit & 017-047 & 0.00 \\
\hline Cyrtomium falcatum & Aboveground part & 016-028 & 4.84 \\
\hline Daphniphyllum macropodum & Leaf & 017-019 & 6.46 \\
\hline Daphniphyllum macropodum & Stem & 017-020 & 0.29 \\
\hline Deutzia prunifolia & Stem & 017-051 & 44.69 \\
\hline Dicentra spectabilis & Aboveground part & 016-010 & 8.22 \\
\hline Diospyros kaki & Leaf & 017-007 & 17.98 \\
\hline Diospyros kaki & Stem & 017-008 & 17.68 \\
\hline Diospyros kaki & Stem-bark & 017-009 & 17.25 \\
\hline Diospyros kaki & Root & 017-011 & 11.64 \\
\hline Dryopteris championi & Whole plant & 016-088 & 6.97 \\
\hline Elaeagnus macrophylla & Leaf & 017-059 & 23.52 \\
\hline Forsythia nakaii & Leaf & 016-085 & 1.93 \\
\hline Fraxinus sieboldiana & Leaf & 017-073 & 9.30 \\
\hline Geranium wilfordii & Whole plant & 017-070 & 42.07 \\
\hline Houttuynia cordata & Whole plant & 016-077 & 7.45 \\
\hline Hydrangea serrata for. acuminata & Aboveground part & 016-058 & 67.16 \\
\hline Hypericum erectum & Whole plant & 017-018 & 6.53 \\
\hline Kalopanax pictus & Stem-heartwood & 016-083 & 14.84 \\
\hline Lilium lancifolium & Aboveground part & 016-091 & 8.82 \\
\hline Lindera erythrocarpa & Leaf & 016-054 & 18.09 \\
\hline
\end{tabular}


Table 1 Effects of plant extracts on the Ag-induced degranulation in RBL-2H3 mast cells (Continued)

\begin{tabular}{|c|c|c|c|}
\hline Lindera erythrocarpa & Stem & 016-055 & 14.20 \\
\hline Lindera obtusiloba & Stem & 016-063 & 19.80 \\
\hline Lycopodium clavatum var. nipponicum & Whole plant & 017-069 & 23.56 \\
\hline Lycoris aurea & Underground part & 017-015 & 52.03 \\
\hline Melandryum seoulense & Whole plant & 017-003 & 62.76 \\
\hline Monochoria vaginalis var. plantaginea & Whole plant & $017-043$ & 2.84 \\
\hline Mosla punctulata & Whole plant & 017-037 & 6.83 \\
\hline Nandina domestica & Leaf & 016-023 & 6.46 \\
\hline Nuphar japonicum & Whole plant & 016-006 & 9.22 \\
\hline Oenothera laciniata & Whole plant & 016-075 & 14.50 \\
\hline Pedicularis resupinata & Whole plant & 017-072 & 35.15 \\
\hline Perilla frutescens var. acuta & Whole plant & 017-071 & 14.14 \\
\hline Persicaria fauriei & Whole plant & 018-003 & 28.89 \\
\hline Persicaria thunbergii & Whole plant & 017-017 & 17.79 \\
\hline Phlomis koraiensis & Aboveground part & 017-064 & 19.72 \\
\hline Phlomis koraiensis & Underground part & 017-065 & 1.94 \\
\hline Phtheirospermum japonicum & Whole plant & $017-024$ & 27.81 \\
\hline Picris hieracioides var. glabrescens & Whole plant & 017-074 & 16.13 \\
\hline Polystichum polyblepharum & Whole plant & $016-020$ & 0.99 \\
\hline Potentilla dickinsii & Whole plant & 017-036 & 7.18 \\
\hline Prunus sargentii & Leaf & 017-062 & 24.50 \\
\hline Prunus takesimensis & Stem-bark & $016-070$ & 52.74 \\
\hline Pyrus pyrifolia & Leaf & 017-034 & 3.85 \\
\hline Pyrus pyrifolia & Stem-bark & 017-035 & 11.10 \\
\hline Rhamnus davurica & Leaf & 017-005 & 92.35 \\
\hline Rhododendron tschonoskii & Leaf & 016-099 & 9.43 \\
\hline Rhododendron tschonoskii & Stem & 016-100 & 25.70 \\
\hline Rhododendron yedoense var. poukhanense & Stem & 016-060 & 16.80 \\
\hline Rhodotypos scandens & Leaf & 017-056 & 14.20 \\
\hline Rodgersia tabularis & Whole plant & 016-005 & 3.83 \\
\hline Salix hallaisanensis & Stem & 016-036 & 31.12 \\
\hline Sanguisorba hakusanensis & Whole plant & 017-068 & 10.22 \\
\hline Sanguisorba tenuifolia var. alba & Whole plant & 017-002 & 29.37 \\
\hline Sorbus commixta & Stem-bark & 016-037 & 22.84 \\
\hline Sorbus commixta & Leaf & 016-038 & 10.86 \\
\hline Sorbus commixta & Stem & 016-039 & 14.46 \\
\hline Sorbus commixta & fruit & 017-039 & 10.32 \\
\hline Spiraea salicifolia & Leaf & 016-016 & 0.00 \\
\hline Stipa sibirica & Whole plant & 017-025 & 46.66 \\
\hline Suaeda asparagoides & Whole plant & $017-026$ & 27.48 \\
\hline Symplocos coreana & Stem & $016-067$ & 3.90 \\
\hline Syringa velutina & Leaf & 016-093 & 0.55 \\
\hline Syringa velutina & Stem & 016-094 & 0.35 \\
\hline Tilia insularis & Stem-bark & 016-071 & 10.69 \\
\hline Tripterygium regelii & Stem & $017-048$ & 31.59 \\
\hline
\end{tabular}


Table 1 Effects of plant extracts on the Ag-induced degranulation in RBL-2H3 mast cells (Continued)

\begin{tabular}{|c|c|c|c|}
\hline Ulmus laciniata & Stem-bark & $016-022$ & 0.00 \\
\hline Veronica kiusiana & Whole plant & $017-028$ & 3.07 \\
\hline Veronica longifolia & Aboveground part & $017-022$ & 4.14 \\
\hline Viburnum sargentii & Leaf & 017-052 & 4.31 \\
\hline Vicia amoena & Whole plant & 017-006 & 27.44 \\
\hline Vicia angustifolia var. minor & Whole plant & 017-001 & 17.50 \\
\hline Vicia unijuga & Whole plant & $017-027$ & 28.89 \\
\hline Vitex rotundifolia & Leaf & 017-075 & 0.63 \\
\hline Vitis thunbergii var. sinuata & Whole plant & $016-014$ & 0.11 \\
\hline Zizyphus jujuba & fruit & 017-042 & 0.00 \\
\hline
\end{tabular}

${ }^{\mathrm{a}}$ The degranulation was assessed through the measurement of the release of the granule marker $\beta$-hexosaminidase from RBL-2H3 mast cells as described in the "Methods" section. The percent inhibition of degranulation is presented as the mean values from three independent experiments.

Extract Bank and Konkuk University. The extracts were solubilized in dimethyl sulfoxide (DMSO) for cell culture experiments and suspended in 5\% Gum arabic for oral administration of extracts in the animal study.

Degranulation assay in mast cells

Mast cells $\left(1.8 \times 10^{5} /\right.$ well $)$ were primed in $50 \mathrm{ng} / \mathrm{ml}$ anti-dinitrophenol (DNP) IgE on 24-well plates for $12 \mathrm{~h}$. The cells were then washed twice with 1,4piperazinediethanesulfonic acid (PIPES)-buffered medium [25 mM PIPES (pH 7.2), $159 \mathrm{mM} \mathrm{NaCl}, 5 \mathrm{mM} \mathrm{KCl}$, $0.4 \mathrm{mM} \mathrm{MgCl}_{2}, 1 \mathrm{mM} \mathrm{CaCl} 2,5.6 \mathrm{mM}$ glucose, and $0.1 \%$ fatty acid-free fraction $\mathrm{V}$ from bovine serum] for RBL-2H3 cells or with Tyrode buffer [20 mM HEPES ( $\mathrm{pH} 7.4$ ), $135 \mathrm{mM} \mathrm{NaCl}, 5 \mathrm{mM} \mathrm{KCl}, 1.8 \mathrm{mM} \mathrm{CaCl}_{2}, 1 \mathrm{mM} \mathrm{MgCl}_{2}$, $5.6 \mathrm{mM}$ glucose, and $0.05 \%$ bovine serum albumin (BSA)] for BMMCs and then pre-incubated in the buffer for $1 \mathrm{~h}$ with or without each plant extract. The mast cells were stimulated by the antigen (DNP-BSA) for $10 \mathrm{~min}$ and the stimulation was terminated using ice. The cultured media were transferred to new tubes and cells were disrupted with $0.1 \%$ triton $\mathrm{X}-100$. For $\beta$-hexosaminidase assay, the culture media and cell lysates were mixed with $1 \mathrm{mM} p$-nitrophenyl-N-acetyl- $\beta$-D-glucosaminide on 96 well plates and incubated at $37^{\circ} \mathrm{C}$ for $1 \mathrm{~h}$. Next, $0.1 \mathrm{M}$ carbonate was used to stop the reaction. The density of the color was measured at $405 \mathrm{~nm}$ by a microplate reader. Degranulation of mast cells was determined by calculating the ratio of $\beta$-hexosaminidase activity released into the culture medium to the total activity of $\beta$-hexosaminidase from the cell lysate plus the culture medium [16].

\section{Assay of cell viability}

BMMCs $\left(5 \times 10^{4} /\right.$ well $)$ were plated on 96 -well plates in serum-free RPMI-1640 medium with or without LERD for $8 \mathrm{~h}$. Then, cell viability was determined by using a cell counting kit-8 (CCK-8) (Dojindo Laboratories, Kumamoto, Japan), according to the manufacturer's protocol. CCK-8 solution was added to each well of the plate at 1:10 ratio to volume of medium, and the plates were incubated for $1 \mathrm{~h}$ in a $\mathrm{CO}_{2}$ incubator at $37^{\circ} \mathrm{C}$. The absorbance of color density was measured at $450 \mathrm{~nm}$.

\section{Measurement of TNF- $a$ and IL-4 expression by reverse transcriptase-polymerase chain reaction (RT-PCR)}

To obtain the total RNA from cells, an Easy-spinTM Total RNA Extraction Kit (iNtRON Biotechnology, Inc., Sungnam, Korea) was used. PCR was performed at $94^{\circ} \mathrm{C}$ for $20 \mathrm{sec}$, at $62^{\circ} \mathrm{C}$ for $10 \mathrm{sec}$, and at $72^{\circ} \mathrm{C}$ for $20 \mathrm{sec}$ for 30 cycles. The primers were used as follows: rat TNF- $\alpha$ forward 5' -ACCACGCTCTTCTGTCTACTGAAC-3'; rat TNF- $\alpha$ reverse: $5^{\prime}$-CCGGACTCCGTGATGTCTAAGTA CT-3'; rat IL-4 forward 5'-ACCTTGCTGTCACCCTG TTC-3'; rat IL-4 reverse 5'-TTGTGAGCGT GGACT CATTC-3'; rat glyceraldehyde-3-phosphate dehydrogenase (GAPDH) forward 5'-GTGGAGTCTACTGGCGTC TTC-3'; rat GAPDH reverse: 5' -CCAAGGC TGTGGGC AAGGTCA-3'.

Measurement of TNF- $a$ and IL-4 in culture media by ELISA RBL-2H3 cells $\left(5.0 \times 10^{5} /\right.$ well $/ 12$ well-clustered plate $)$ were plated with $50 \mathrm{ng} / \mathrm{ml}$ DNP-specific IgE overnight. Cells were stimulated by antigen with or without LERD for $8 \mathrm{~h}$ at $37^{\circ} \mathrm{C}$ and then the culture media were analyzed via the ELISA kit according to manufacturer's protocol.

\section{Immunoblotting analysis}

The IgE-primed RBL-2H3 cells were stimulated with $25 \mathrm{ng} / \mathrm{ml}$ antigen for $7 \mathrm{~min}$ or as indicated. The cells were lysed with ice-cold lysis buffer $(20 \mathrm{mM}$ HEPES, $\mathrm{pH}$ 7.5, $150 \mathrm{mM} \mathrm{NaCl}, 1 \%$ Nonidet p-40, 10\% glycerol, $60 \mathrm{mM}$ octyl $\beta$-glucoside, $10 \mathrm{mM} \mathrm{NaF}, 1 \mathrm{mM} \mathrm{Na} 3 \mathrm{VO}_{4}$, 
$1 \mathrm{mM}$ phenylmethylsulfonyl fluoride, $2.5 \mathrm{mM}$ nitrophenylphosphate, $0.7 \mu \mathrm{g} / \mathrm{ml}$ pepstatin and protease inhibitor cocktail tablet). Lysates were kept on ice for $30 \mathrm{~min}$ and then centrifuged at $13,000 \times g$ for $10 \mathrm{~min}$ at $4^{\circ} \mathrm{C}$. After centrifuging, the supernatant proteins were denatured at $95^{\circ} \mathrm{C}$ for $5 \mathrm{~min}$ in a $3 \times$ Laemmli buffer [17]. The denatured proteins were separated by sodium dodecylsulfate (SDS)-polyacrylamide gel electrophoresis (PAGE) and then transferred to a nitrocellulose membrane. The transferred protein membrane was blocked in trisbuffered saline- $0.05 \%$ Tween 20 (TBS-T) buffer containing $5 \%$ BSA. The membrane was incubated overnight with the specific antibody for the target protein. After washing the membrane with TBS-T buffer, it was incubated with a labeled secondary antibody directed against the primary antibody. The protein bands for immunoreactive proteins were detected with horseradish peroxidase (HRP)-coupled secondary antibodies and enhanced chemiluminescence according to manufacturer's protocol (Amersham Biosciences, Piscataway, NJ, USA).

\section{Passive cutaneous anaphylaxis (PCA) and histological analysis}

PCA was generated in mice according to a previous study [18]. DNP-specific IgE (0.5 $\mu$ g per mouse) was intradermally injected into the right ear of a BALB/c mouse (male, 5 weeks old). After 24 h, LERD (0, 100,
300 , and $1,000 \mathrm{mg} / \mathrm{kg}$ ) or cetirizine $(20 \mathrm{mg} / \mathrm{kg})$ was orally administered to the mice. After $60 \mathrm{~min}$, the mice were intravenously injected with $250 \mu \mathrm{g}$ of antigen in Evans blue solution ( $5 \mathrm{mg} / \mathrm{ml} \mathrm{PBS}$ ). The ears were collected after the mice were euthanized $1 \mathrm{~h}$ later. The dye of ear tissue was extracted overnight in $700 \mu \mathrm{l}$ of formamide at $63^{\circ} \mathrm{C}$ and then the absorbance was analyzed at $620 \mathrm{~nm}$. For histological analysis, ear tissues were fixed in $4 \%$ paraformaldehyde in PBS for 24 h. $5-\mu \mathrm{m}$ paraffin sections were stained with $0.1 \%$ toluidine blue and examined with an optical microscope (Olympus DP 70, Center Valley, PA, USA) at $\times 100$ magnification. Degranulated mast cells in the ear tissue were counted as previously described [19].

\section{Measurement of tyrosine kinase activity in vitro}

After stimulating IgE-primed mast cells with $25 \mathrm{ng} / \mathrm{ml}$ antigen for $7 \mathrm{~min}$, Lyn or Fyn were immunoprecipitated from whole cell lysates by using specific antibodies. The activity of tyrosine kinase was measured using a Universal Tyrosine Kinase Assay Kit (Gen Way, San Diego, USA) according to manufacturer's instruction.

\section{Presentation of results}

The data were presented as the means \pm SEM from three or more independent experiments. Statistical analysis was performed by using one-way ANOVA and the Dunnett
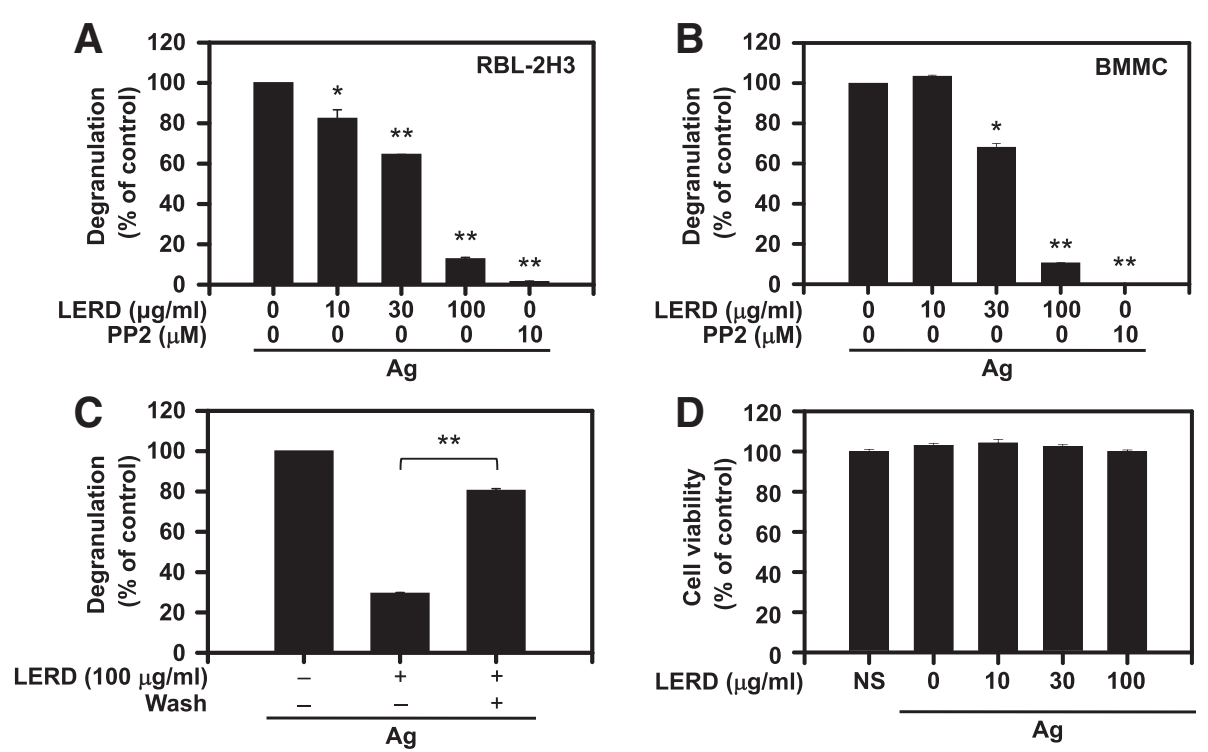

Figure 1 LERD reversibly inhibits antigen-stimulated degranulation in mast cells. RBL-2H3 mast cells (A) and BMMCs (B) were incubated overnight in 24-well cluster plates with $50 \mathrm{ng} / \mathrm{ml}$ of lgE in a complete growth medium. The lgE-primed mast cells were stimulated by antigen ( $25 \mathrm{ng} / \mathrm{ml})$ with or without LERD. The activity of $\beta$-hexosaminidase was measured as described in the "Methods" section. (C) RBL-2H3 cells were pre-incubated for $1 \mathrm{~h}$ with $0.1 \%$ DMSO or $100 \mu \mathrm{g} / \mathrm{ml}$ LERD. After LERD-treated cells were washed five times with PIPES buffer, degranulation of mast cells was measured as for panel A. (D) BMMCs were incubated with LERD for $8 \mathrm{~h}$ and the cell viability, then, was measured as described in the "Methods" section. The mean \pm SEM from three independent experiments are shown here. Asterisks indicate significant differences from the controls, ${ }^{*} P<0.05$ and ${ }^{*} P<0.01$. PP2 is a general Src family kinase inhibitor. 
test. All statistical calculations ( ${ }^{*} \mathrm{P}<0.05$ and $\left.{ }^{* *} \mathrm{P}<0.01\right)$ were performed with SigmaStat software (Systat Software Inc., Point Richmond, CA, USA).

\section{Results}

The effects of LERD and other herbal extracts on antigen-stimulated degranulation in mast cells

Mast cells have secretary granules containing allergic mediators such as histamine and various proteases that cause allergic symptoms [20]. Thus, the effects of approximately 100 herbal extracts on the degranulation of mast cells were firstly measured in RBL-2H3 mast cells. The extracts from Vitex rotundifolia, Prunus sargentii, Lycoris aurea, Hydrangea serrata for. acuminata, Prunus takesimensis, Clintonia udensis, and Rhamnus davurica significantly inhibited degranulation $(>50 \%)$ at a concentration of $100 \mu \mathrm{g} / \mathrm{ml}$ in RBL-2H3 cells (Table 1 ). Among them, LERD most potently suppressed degranulation, release of $\beta$-hexosaminidase, in antigenstimulated RBL-2H3 mast cells or BMMCs in a dose dependent manner (Figure 1A and B). However, LERD did not inhibit the activity of $\beta$-hexosaminidase released from mast cells (data not shown). When mast cells were washed twice with the incubation buffer after pretreating with LERD for $1 \mathrm{~h}$, the degranulation of mast cells was almost completely recovered (Figure 1C), indicating that the effect of LERD on mast cell activation was reversible. Notably, no effect on the viability of mast cells was observed by LERD at the experimental doses (Figure 1D).

\section{Effect of LERD on the expression and secretion of inflammatory cytokines}

In addition to degranulation in mast cells, mast cells also secrete various inflammatory cytokines. Among them, TNF- $\alpha$ and IL- 4 are secreted in antigen- stimulated cells. Therefore, we measured the expression levels of TNF- $\alpha$ and IL- 4 by RT-PCR. As shown in Figure $2 \mathrm{~A}$, the expression of TNF- $\alpha$ and IL-4 was dosedependently suppressed in antigen-stimulated mast cells. The secretion levels of TNF- $\alpha$ and IL-4 were also analyzed by ELISA assay. The secretion of TNF- $\alpha$ and IL-4 was consistently inhibited in a dose dependent manner (Figure 2B).

\section{Effect of LERD on activations of signaling molecules by antigen}

Next, to ascertain the mechanism of the LERD action, we investigated which intracellular signaling molecules were affected by LERD treatment. It is well known that Syk and its direct substrate protein LAT pathway is a pivotal signaling cascade for mast cell activation [12]. LERD suppressed the activation of Syk and LAT in RBL-2H3 cells and BMMCs

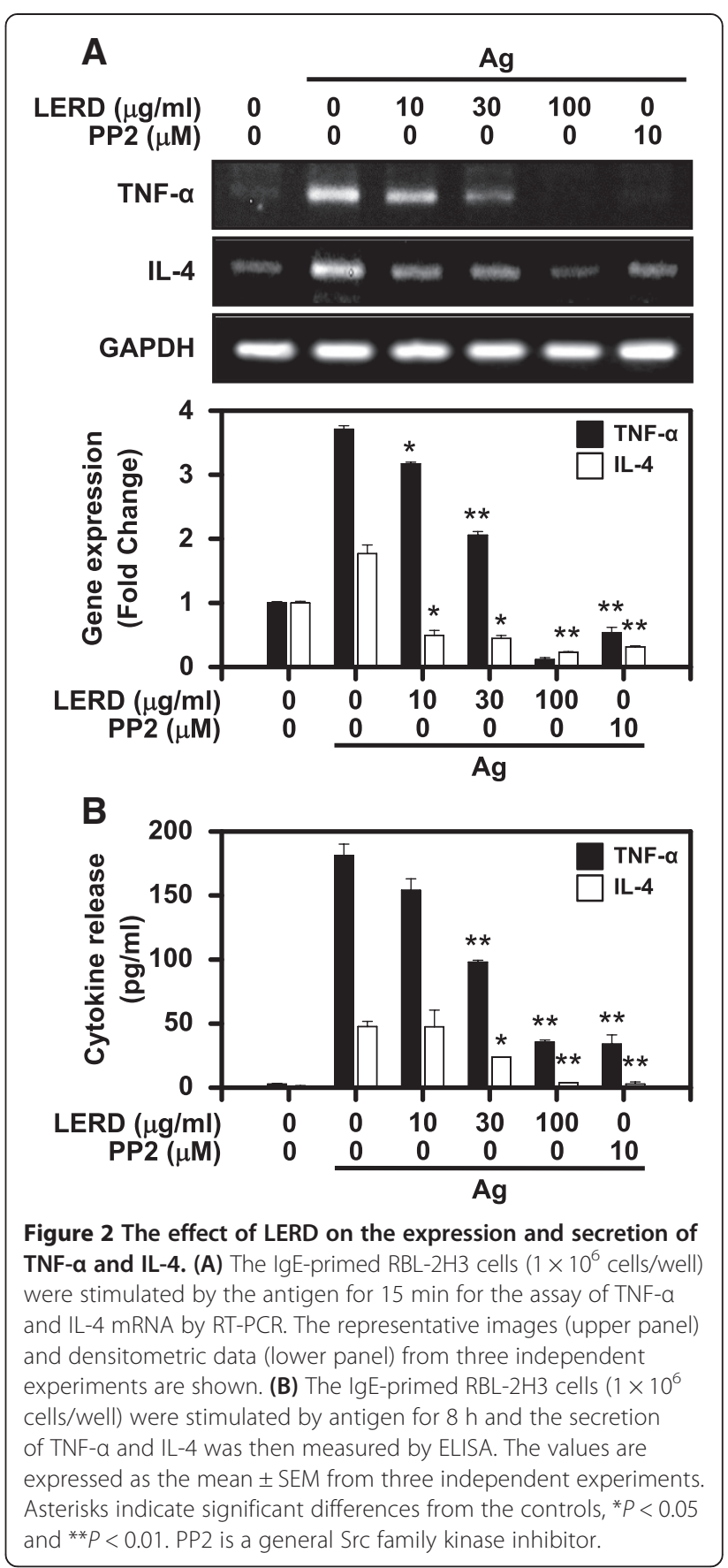

(Figure 3). At a dose of $30 \mu \mathrm{g} / \mathrm{ml}$, the inhibition was obvious and was nearly complete at $100 \mu \mathrm{g} / \mathrm{ml}$ (Figure 3). Next, we also studied MAP kinase signaling pathway which is generally accepted that three typical MAP kinases are critical for the production of inflammatory cytokines from mast cells [21,22]. In this experiment, LERD significantly reduced the activation of ERK1/2, p-38 and JNK in a dose dependent manner (Figure 3 ). 


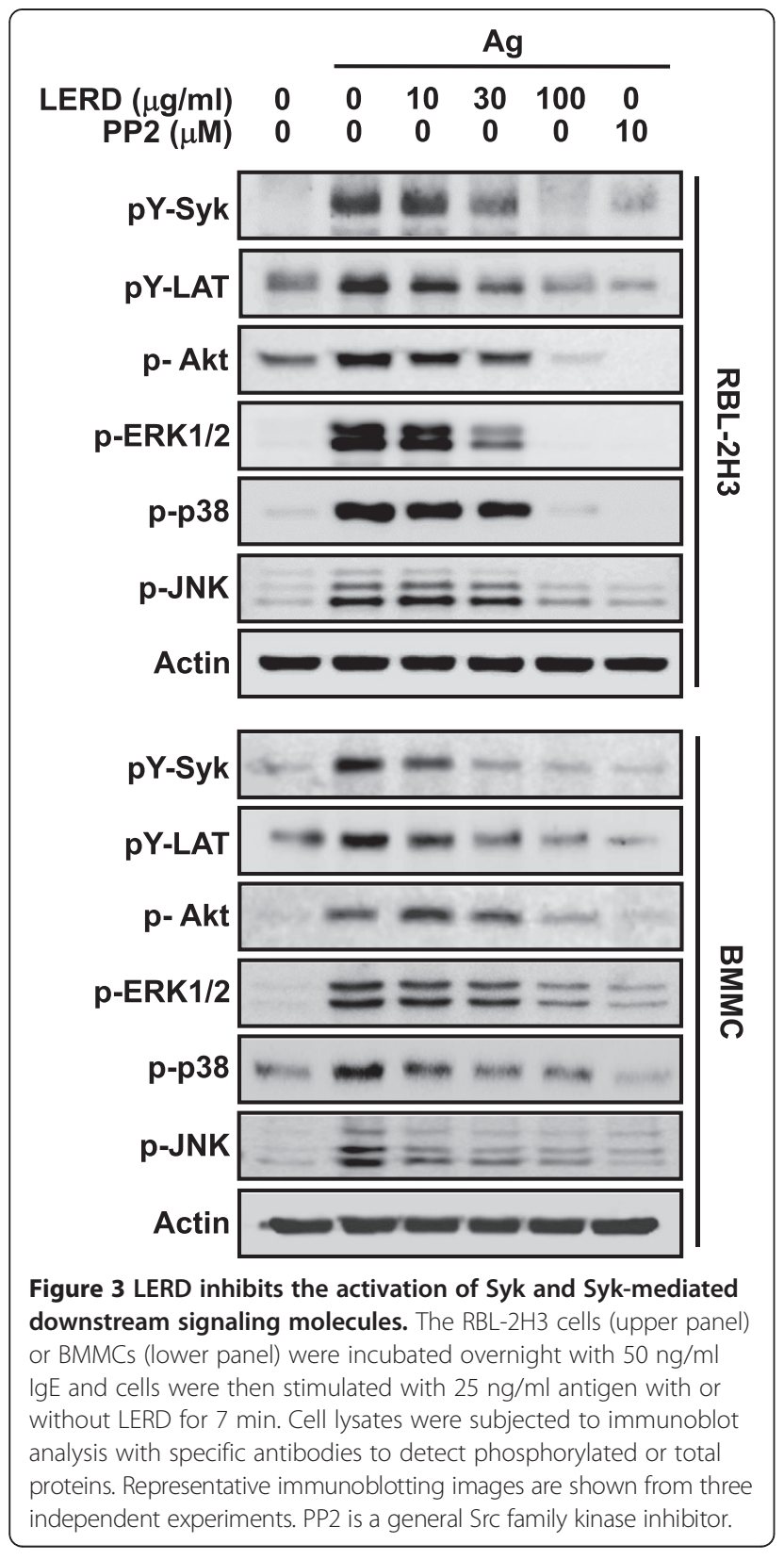

LERD inhibited activity of Fyn, but not Lyn, in antigen-stimulated mast cells

Several lines of evidence suggest that Lyn is the initially activated tyrosine kinase in antigen-stimulated mast cells. The aggregation of IgE-high affinity receptor (FceRI) by antigen initially leads to the activation of Lyn for downstream signaling molecules [12]. Another tyrosine kinase, Fyn, is also activated in mast cells by antigen for a complementary pathway to stimulate full activation of mast cells [23]. LERD did not show any suppressive effect on the expressions of FceRI subunits (Figure 4A). Next, we tested whether LERD suppressed the upstream tyrosine kinases of Syk, Lyn, or Fyn in the cells. As shown in Figure 4B,

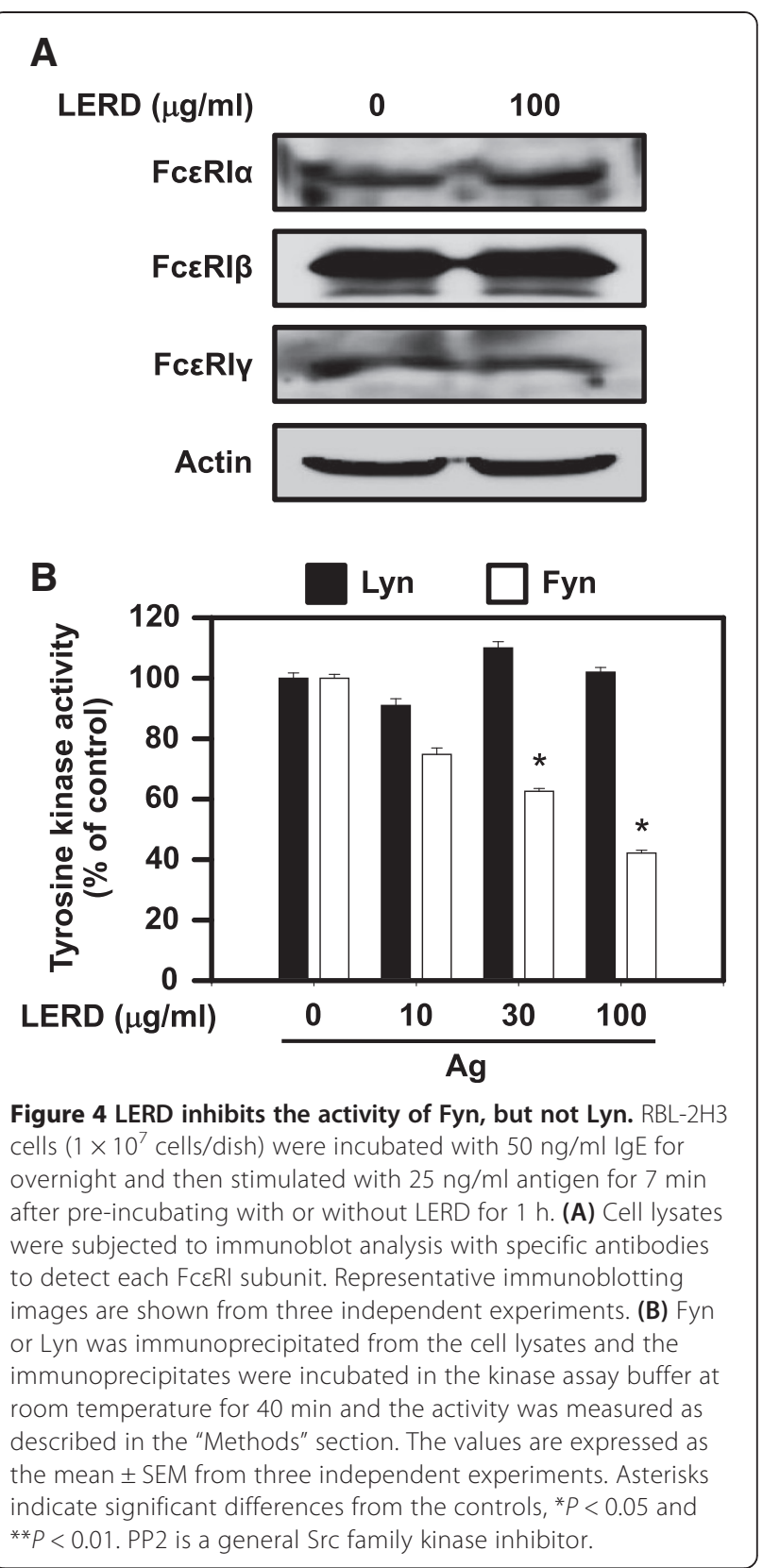

LERD inhibited activation of Fyn, but not Lyn, in a dose dependent manner.

Effect of LERD on passive cutaneous anaphylaxis (PCA) in mice

To determine the anti-allergic effect of LERD in vivo, a PCA model was used in BALB/c mice. Histological analysis was further performed to check whether LERD inhibited mast cell degranulation in mouse ear tissues. The PCA responses were successfully induced by the injection of $\mathrm{IgE} /$ antigen in mice. LERD significantly inhibited the response in a dose dependent manner (Figure 5A). In the histological analysis with ear tissues, 

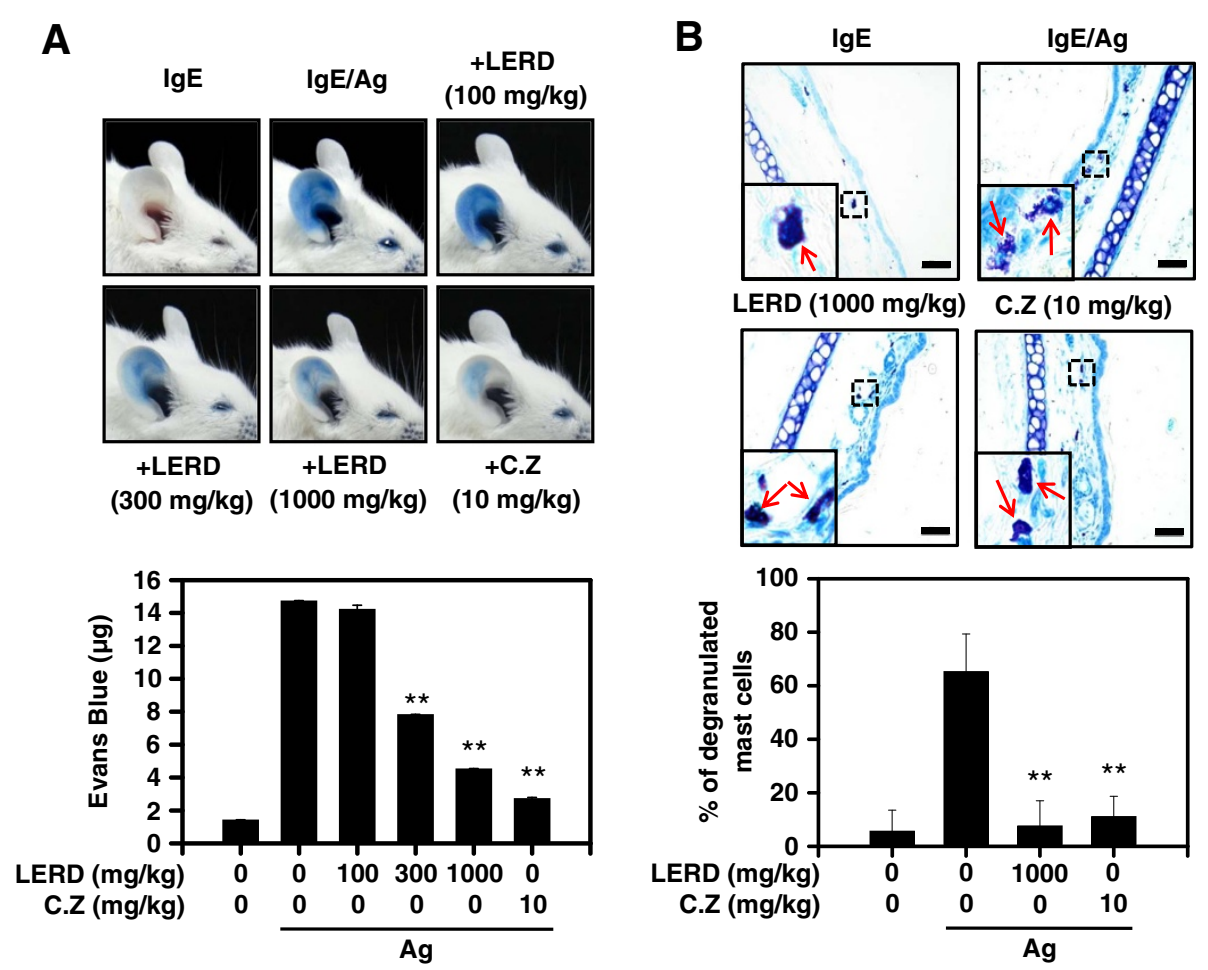

Figure 5 LERD suppresses passive cutaneous anaphylaxis in vivo. An lgE $(0.5 \mu \mathrm{g})$ was intradermally injected into the mouse ear. After $24 \mathrm{~h}$, an injection of $250 \mathrm{\mu g}$ antigen in 4\% Evans blue PBS solution was administered into the mouse tail vein. The LERD was orally administered $1 \mathrm{~h}$ before the treatment of the antigen. The mouse was euthanized $1 \mathrm{~h}$ after the antigen challenge, and the ear was then removed for measurement of the amount of dye extravasated (A) or histological changes (B) by antigen treatment. (A) Representative photographs of ears after PCA (upper panel) and quantitative data for ear-tissue content of Evans blue (lower panel). (B) The ear tissues were prepared and stained with toluidin blue for histological examination as described in the "Methods" section. Representative images (upper panel) and the percentage of degranulated mast cells in ear skin sections (lower panel) are shown: arrows indicate mast cells. bar, $50 \mu \mathrm{m}$. The values are expressed as the mean \pm SEM from three independent experiments. ${ }^{*} \mathrm{P}<0.05$ and ${ }^{* * P}<0.01$.; C.Z., cetirizine.

LERD suppressed the degranulation of tissue mast cells by antigen (Figure $5 \mathrm{~B}$ ). These results suggested that LERD has an anti-allergic effect in vivo through the inhibition of mast cells.

\section{Discussion}

Allergic diseases such as asthma, allergic rhinitis, and atopic dermatitis are on the rise, particularly, in developed countries. It has been generally accepted that when people who are skewed to Th2 intake or come into physical contact with a specific allergen, they suffer from allergic symptoms. A large body of evidence suggests that mast cell is a key player of acute and chronic allergic inflammation in allergic diseases [20]. In this context, stimulation of mast cells by antigen results in the release of a variety of mediators such as histamine and an array of inflammatory cytokines that cause allergic symptoms $[6,12]$. Therefore, the regulation of mast cells is one of the potential therapeutic approaches for the development of allergy medication. In this study, we demonstrated for the first time that
LERD suppresses mast cell-mediated PCA in mice by inhibiting the activation of the Fyn/Syk signaling pathway in mast cells.

Mast cells play a critical role in immune response when a foreign antigen infiltrates a human body. When mast cells are stimulated by antigen, they release preformed granule-associated mediators, such as histamine, serotonin, and $\beta$-hexosaminidase, eicosanoids, inflammatory cytokines, and chemokines [24,25]. These mediators lead to certain pathophysiological changes and tissue remodeling for various allergic symptoms.

The effects of drugs are generally reversible in a human body. After a certain period following the administration of a drug, the function of drug-target molecule returns to normal functioning status. If the action of a drug, on the other hand, is irreversible, its effect persists until the body generates additional protein. Therefore, it is critical to check at the early stage of the drug development whether a candidate is reversible. The inhibition of LERD on mast cell activation was reversible (Figure 1C), suggesting that 
LERD achieves its effect by reversibly suppressing the activations of signaling molecules in antigen-stimulated mast cells.

Accumulating evidence from mice and humans has argued that Th2 cytokines such as IL-4, IL-5, and IL-13 are contributors to allergic responses [26]. Mast cells secrete the cytokines. Apart from these Th2 cytokines, TNF- $\alpha$, one of the critical inflammatory cytokines, is also secreted from mast cells [12]. In this study, LERD suppressed the expression and secretion of IL- 4 and TNF- $\alpha$ in antigen-stimulated mast cells (Figure 2). The results further suggested that LERD may have a therapeutic potential in cytokineassociated allergic symptoms in allergic patients.

In the atopic environment, mast cells are activated by binding antigen to the IgE that is bound to its multimeric receptor, FceRI. The aggregation of FceRIs leads to the phosphorylation of tyrosine residues of the ITAMs of FceRI by Lyn and, subsequently, activation of Syk, a pivotal signaling molecule for mast cell activation by the antigen. Syk is essential for the activation of many downstream signaling molecules including LAT adaptor protein. The activation of Syk is also critical for the activation of Akt and three typical MAP kinases (ERK1/2, p38, and JNK). In such a manner, mast cells are activated to release an array of allergic mediators [12]. In this study, LERD inhibited activation of Syk and LAT in antigenstimulated mast cells (Figure 3), suggesting that its inhibition of Syk activation was a key mechanism of LERD.

Fyn is an essential signaling molecule for full activation of antigen-stimulated mast cells. The activation of Fyn is critical for the activation of the Gab2/PI3-K/Akt pathway [23]. In other reports, Fyn is also important for the activation of Syk [11,27]. Of note, our study found that LERD inhibited only the activity of Fyn, not Lyn, in antigen-stimulated mast cells (Figure 4B), suggesting that LERD suppressed the activation of Fyn and Fyn/ Syk-mediated downstream signaling molecules.

Anaphylaxis is an allergic response that is remarkably dangerous and acute as it can cause death due to asphyxiation. Systemic or local anaphylaxis may occur when the exterior allergens such as insect venom, food, and pollen infiltrate the allergic patient's body [28]. The reactions cause the release of inflammatory mediators and cytokines from mast cells and basophils [29]. To confirm the anti-allergic effect of LERD in animal model, we utilized IgE-mediated PCA mice. In the mice, LERD remarkably suppressed the anaphylactic responses (Figure 5A) and degranulation of mast cells in ear (Figure 5B). Taken together, the results demonstrated that LERD has an anti-allergic effect in vivo.

\section{Conclusions}

Our results demonstrated for the first time that LERD suppresses degranulation and cytokine production in

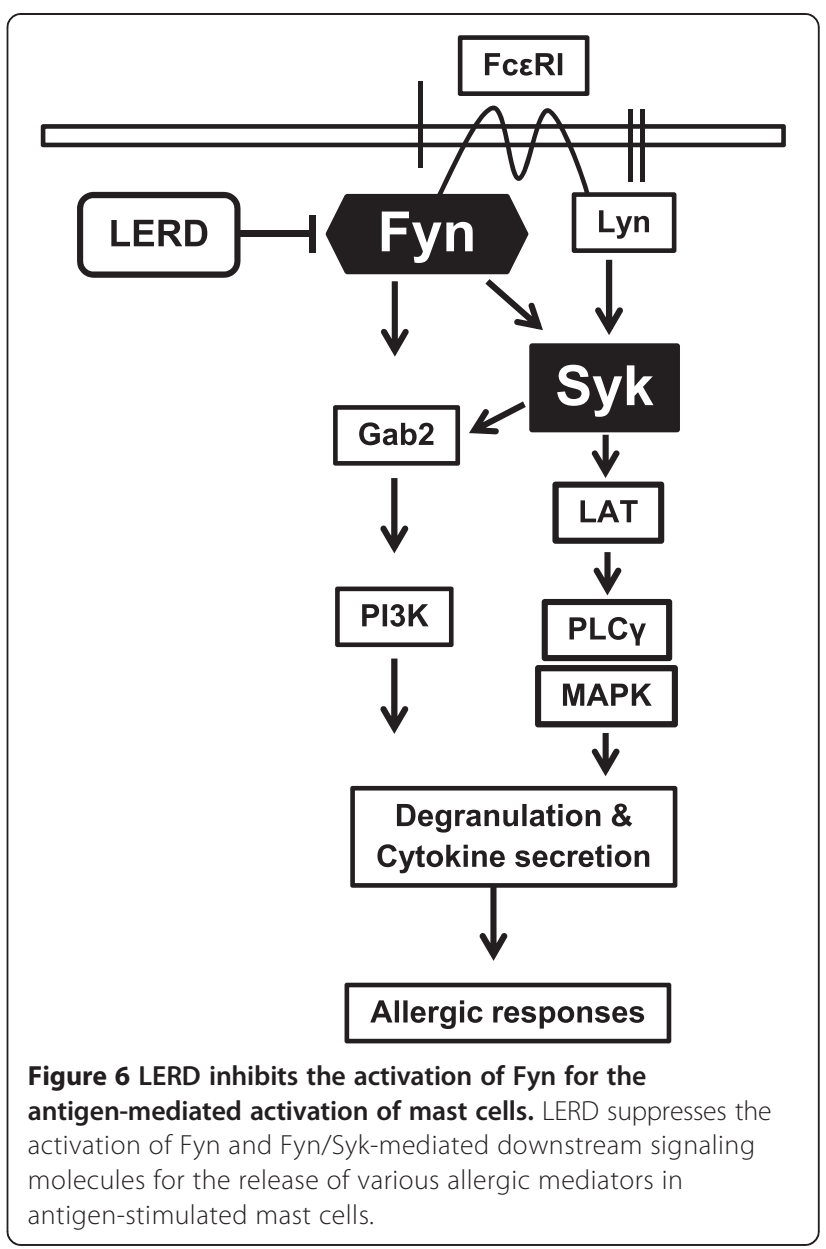

antigen-stimulated mast cells and, furthermore, inhibits IgE-mediated allergic responses in mice. Mechanically, LERD suppresses the activation of Fyn/Syk pathway and its downstream signaling molecules to supress secretion of allergic mediators in mast cells (Figure 6). Although further comprehensive studies for bioavailability, toxicity, and active components of LERD are required for the development of drug, our finding suggested that LERD may be a useful herbal extract for human allergic diseases.

\section{Abbreviations}

BMMC: Bone marrow-derived mast cell; DNP: 2,4-Dinitrophenyl; LAT: Linker for activation of T cells; MAP: Mitogen-activated protein; PCA: Passive cutaneous anaphylaxis.

\section{Competing interests}

The authors declare that they have no competing interests.

\section{Authors' contributions}

JHK, ARK and HSK performed most experiments and wrote a draft manuscript. HWK and YHP performed experiments with animal study. JSY performed in vitro kinase activity. YMP did experiments with RBL-2H3 cells. EH and HSK provided comments and performed RT-PCR and densitometry. YMK and WSC designed most experiments, interpreted data, wrote the final manuscript, and supervised the whole project. All authors read and approved the final manuscript 


\section{Acknowledgements}

This work was supported by the National Research Foundation of Korea (NRF) grant funded by the Korea government (MSIP, No. 2012R1A2A1A03670516) and in part by a National Research Foundation of Korea (NRF) grant (MSIP, NRF-2013R1A4A1069575).

\section{Author details}

${ }^{1} \mathrm{KU}$ open Innovation Center, School of Medicine, Konkuk University, Chungju 380-701, Korea. ${ }^{2}$ College of Pharmacy, Sungkyunkwan University, Suwon 440-746, Korea. ${ }^{3}$ College of Pharmacy, Duksung Women's University, Seoul 132-714, Korea.

Received: 3 June 2014 Accepted: 12 March 2015

Published online: 25 March 2015

\section{References}

1. Erb KJ. Can helminths or helminth-derived products be used in humans to prevent or treat allergic diseases? Trends Immunol. 2009;30:75-82.

2. Flohr C, Quinnell RJ, Britton J. Do helminth parasites protect against atopy and allergic disease? Clin Exp Allergy. 2009;39:20-32.

3. Voehringer D. Protective and pathological roles of mast cells and basophils Nat Rev Immunol. 2013:13:362-75.

4. Bischoff SC. Role of mast cells in allergic and non-allergic immune responses: comparison of human and murine data. Nat Rev Immunol. 2007;7:93-104

5. Gregory GD, Brown MA. Mast cells in allergy and autoimmunity: implications for adaptive immunity. Methods Mol Biol. 2006;315:35-50,

6. Beaven MA. Our perception of the mast cell from Paul Ehrlich to now. Eur J Immunol. 2009;39:11-25.

7. Rivera J, Gilfillan AM. Molecular regulation of mast cell activation. J Allergy Clin Immunol. 2006:117:1214-25.

8. Galli SJ, Tsai M, Piliponsky AM. The development of allergic inflammation. Nature. 2008:454:445-54

9. Kinet JP. The essential role of mast cells in orchestrating inflammation Immunol Rev. 2007:217:5-7.

10. Siraganian RP, Zhang J, Suzuki K, Sada K. Protein tyrosine kinase Syk in mast cell signaling. Mol Immunol. 2002:38:1229-33.

11. Lee JH, Kim JW, Kim DK, Kim HS, Park HJ, Park DK, et al. The Src family kinase Fgr is critical for activation of mast cells and lgE-mediated anaphylaxis in mice. J Immunol. 2011;187:1807-15.

12. Gilfillan AM, Beaven MA. Regulation of mast cell responses in health and disease. Crit Rev Immunol. 2011;31:475-529.

13. Alvarez-Errico D, Lessmann E, Rivera J. Adapters in the organization of mast cell signaling. Immunol Rev. 2009:232:195-217.

14. Odom S, Gomez G, Kovarova M, Furumoto Y, Ryan JJ, Wright HV, et al. Negative regulation of immunoglobulin E-dependent allergic responses by Lyn kinase. J Exp Med. 2004;199:1491-502.

15. Jensen BM, Swindle EJ, Iwaki S, Gilfillan AM. Generation, isolation, and maintenance of rodent mast cells and mast cell lines. Curr Protoc Immunol 2006;3.23.1-3.23.13. doi:10.1002/0471142735.im0323s74

16. Ozawa K, Szallasi Z, Kazanietz MG, Blumberg PM, Mischak H, Mushinski JF, et al. $\mathrm{Ca}(2+)$-dependent and $\mathrm{Ca}(2+)$-independent isozymes of protein kinase $\mathrm{C}$ mediate exocytosis in antigen-stimulated rat basophilic RBL-2H3 cells. Reconstitution of secretory responses with $\mathrm{Ca} 2+$ and purified isozymes in washed permeabilized cells. J Biol Chem. 1993;268:1749-56.

17. Laemmli UK. Cleavage of structural proteins during the assembly of the head of bacteriophages t4. Nature. 1970;227:680-5.

18. Kim DK, Kim HS, Kim AR, Jang GH, Kim HW, Park YH, et al. The scaffold protein prohibitin is required for antigen-stimulated signaling in mast cells. Sci Signal. 2013;6:ra80.

19. Kim DK, Kim HS, Kim AR, Kim JH, Kim B, Noh G, et al. DJ-1 regulates mast cell activation and IgE-mediated allergic responses. J Allergy Clin Immunol. 2013;131:53-62.

20. Galli SJ, Tsai M. IgE and mast cells in allergic disease. Nat Med. 2012;18:693-704

21. Law CL, Chandran KA, Sidorenko SP, Clark EA. Phospholipase Cgamma1 interacts with conserved phosphotyrosyl residues in the linker region of Syk and is a substrate for Syk. Mol Cell Biol. 1996:16:1305-15.

22. Saitoh S, Odom S, Gomez G, Sommers CL, Young HA, Rivera J, et al. The four distal tyrosines are required for LAT-dependent signaling in FcepsilonRI-mediated mast cell activation. J Exp Med. 2003;198:831-43.
23. Parravicini V, Gadina M, Kovarova M, Odom S, Gonzalez-Espinosa C, Furumoto $Y$, et al. Fyn kinase initiates complementary signals required for IgE-dependent mast cell degranulation. Nat Immunol. 2002;3:741-8.

24. Theoharides TC, Cochrane DE. Critical role of mast cells in inflammatory diseases and the effect of acute stress. J Neuroimmunol. 2004;146:1-12.

25. Theoharides TC, Kalogeromitros D. The critical role of mast cells in allergy and inflammation. Ann N Y Acad Sci. 2006;1088:78-99.

26. Licona-Limón P, Kim LK, Palm NW, Flavell RA. TH2, allergy and group 2 innate lymphoid cells. Nat Immunol. 2013;14:536-42.

27. Yu M, Luo J, Yang W, Wang Y, Mizuki M, Kanakura Y, et al. The scaffolding adapter Gab2, via Shp-2, regulates kit-evoked mast cell proliferation by activating the Rac/JNK pathway. J Biol Chem. 2006;281:28615-26.

28. Simons FE. World Allergy Organization: World Allergy Organization survey on global availability of essentials for the assessment and management of anaphylaxis by allergy-immunology specialists in health care settings. Ann Allergy Asthma Immunol. 2010;104:405-12.

29. Khan BQ, Kemp SF. Pathophysiology of anaphylaxis. Curr Opin Allergy Clin Immunol. 2011;11:319-25.

\section{Submit your next manuscript to BioMed Central and take full advantage of:}

- Convenient online submission

- Thorough peer review

- No space constraints or color figure charges

- Immediate publication on acceptance

- Inclusion in PubMed, CAS, Scopus and Google Scholar

- Research which is freely available for redistribution 